Marianne Leikvoll Eide

Avdeling for lcerarutdanning

Høgskulen på Vestlandet

E-post: Marianne.Leikvoll.Eide@hvl.no

May Britt Revheim Brekke

Avdeling for lcerarutdanning

Høgskulen på Vestlandet

Asle Holthe

Avdeling for lcerarutdanning

Høgskulen på Vestlandet

\title{
Teoriens manglende plass i praksissamtalen
}

\section{Sammendrag}

I denne artikkelen settes søkelyset på praksissamtalen som gjennomføres når lererstudenter er i praksis. Studentgruppen møter praksislærer på praksisskolen og faglcerer fra høgskolen etter en planlagt og gjennomført undervisningsøkt. En av intensjonene $i$ en integrert lcererutdanning er å utvikle lcererprofesjonalitet ved å koble praksis og teori.

Gjennom fokusgruppeintervju med to studentgrupper undersøkte vi problemstillingen: Hvordan opplever og forstår leererstudentene praksissamtalens hensikt, innhold og kontekst? Teoretisk utgangspunkt for analysen var ulike tilncerminger til profesjoners kunnskapsgrunnlag og litteratur om relasjonsaspektet $i$ faglige dialoger.

Studentenes sterke vektlegging av relasjonelle og emosjonelle aspekter ved praksissamtalens kontekst og deres manglende forståelse av teoriens plass $i$ samtalen, var iøynefallende i dette datamaterialet. Deres forståelse av praksis og teori som to atskilte verdener bekreftet tidligere undersøkelser. Resultatene viser at utfordringer og støtte må balanseres i den faglige praksissamtalen, slik at det relasjonelle aspektet bidrar til å fremme, ikke hemme, faglige utfordringer i samtalen.

Med utgangspunkt i resultatene drøftes studentenes behov for trygghet og trivsel og deres sårbarhet i veiledningssamtaler, opp mot behovet for utvikling av lcererprofesjonalitet gjennom profesjonens allsidige kunnskapsgrunnlag. Artikkelen argumenterer for at det å utfordre kan vœre en form for støtte, og at ulike kunnskapsformer bør praktiseres $i$ en dialogisk praksissamtale for at studentene skal oppleve helhet og sammenheng i lererutdanningen.

Nøkkelord: praksissamtale, lcererutdanning, lererprofesjonalitet, teori/praksis, kunnskapsformer, dialog 


\section{Abstract}

This article focuses on the student-supervisor conversations that take place when student teachers are out in practice. Following planned teaching sessions at their practice schools, student groups meet with their practice-training supervisors and subject teachers from the college. This helps to fulfil one of the aims of an integrated teacher education programme, which is to develop teacher professionalism by connecting practice and theory.

Based on focus-group interviews with two student groups, we investigated the question: How do student teachers experience and perceive the purpose of the student-supervisor conversations in practice - the content and context? The theoretical basis for the analysis was various approaches to the knowledge basis of professions, and literature about issues of relations in professional conversations.

A striking feature of the material was the great stress the students placed on the relational and emotional aspects of the student-supervisor conversations, and their lack of understanding of the role of theory in the conversation. Their perception of practice and theory as two distinct worlds confirms earlier research findings. The results reveal that there must be a balance between challenges and support in the professional conversations, so that the relational aspect can help to promote rather than inhibit discussions of professional challenges.

Based on the results, the discussion highlights the students' need for security and well-being, and their vulnerability in the supervision conversations, juxtaposed to the need to develop teacher professionalism founded on the profession's comprehensive knowledge base. This article argues that challenging may be a kind of support, and that both practical and theoretical forms of knowledge are important if students are to experience the totality and connections within teacher education in a dialogical student-supervisor conversation.

Keywords: student-supervisor conversation, teacher education, teacher professionalism, theory/practice, forms of knowledge, dialogue

\section{Innledning}

I grunnskolelærerutdanningene (GLU) som ble etablert i 2010, er profesjonsaspektet vektlagt. Det ble i større grad lagt opp til sammenheng og integrering mellom praksis og teori enn tidligere (UHR, 2011, s. 22). Studentenes læring og utvikling av lærerprofesjonalitet skjer blant annet gjennom oppgaver og erfaringer i praksisfeltet som det systematisk knyttes refleksjon og teori til. For at lærerutdanningen skal være en profesjonsutdanning, og ikke en "teknikerutdanning”, er det nødvendig at studentene får et teoretisk kunnskapsgrunnlag 
som de bruker aktivt i refleksjon over praksis. Gjennom dette får studentene mulighet til å utvikle klokskap, skjønn og dømmekraft i yrkesutøvelsen.

En felles møteplass for studentgruppen, praksislærer og faglærer fra høgskolen er praksissamtalen, også kalt trepartsamtalen eller praksismøtet. Her møtes de tre partene til veiledningssamtale etter en undervisningsøkt som er planlagt og gjennomført av studentene. Praksissamtalen kan, som felles møtested for de tre partene, være en kilde til utvikling av lærerprofesjonalitet i skjæringspunktet mellom teori og praksis, og indikerer et samarbeid mellom tre parter som ut fra hver sine posisjoner og ståsteder deltar i samtalen. Målet med denne artikkelen er å bidra med kunnskap om betydningen det faglige kunnskapsgrunnlaget og relasjonelle forhold har for studentene i praksissamtalen. Vi søker å belyse denne problemstillingen: Hvordan opplever og forstår lcererstudentene praksissamtalens hensikt, innhold og kontekst?

\section{Teoretiske perspektiver}

Det faglige kunnskapsgrunnlaget i studentenes profesjonsutvikling kan bygge på ulike kunnskapsformer. Tidligere forskning peker på at lærerutdanningens teoridel og praksisdel for studentene oppleves som to kloder (Skagen, 2009). Praksis /teori-problemet er et av de mest sentrale og omstridte spørsmål i pedagogikken og i profesjonsutdanninger (Kvernbekk, 2001, 2011; Grimen, 2008). Teori og praksis bør ikke oppfattes som en dikotomi, men som et begrepspar som gir mening i forhold til hverandre (Dysthe, 2001; Rørnes, 2015). Distinksjonen mellom teori og praksis kan redusere mulighetene for å se på forholdet mellom ulike kunnskapsformer (Ludvigsen, 2015). Begrepene praktisk og teoretisk kunnskap er ikke entydige, og det finnes flere typer forhold mellom teori og praksis (Grimen, 2008). Teoriens plass i praksissamtaler er derfor ikke opplagt og åpenbar. Ifølge Fosse (2016) er utfordringer med å transformere kunnskap mellom de ulike læringskontekstene campus og skole et læringsproblem for studentene.

Ifølge Kvernbekk oppfatter lærerstudenter at teori er til lite hjelp i praksis (2001). Erfaring oppleves som mer nyttig da den bygger på egne slutninger om hva som fungerer. Kunnskapen er da indeksert, uløselig knyttet til utøveren og hans handlinger (Grimen, 2008). Men slike egne teorier om praksis kan ikke uten videre overføres til andre, lignende partikulære situasjoner. Det er imidlertid forståelig at lærerstudenter har behov for å lære seg praktiske ferdigheter. Ifølge Eraut (1985) har praktikeren bruk for "know-how-kunnskap", selv om også han ser utfordringer knyttet til den partikulære kunnskapen. Behovet for slik nyttig kunnskap kan, ifølge Eraut, føre til en skepsis til boklig kunnskap som ikke kan dekke det akutte kunnskapsbehovet når det "brenner" i klasserommet. Når handlingstvangen er umiddelbar, vil abstrakt kunnskap ikke være til hjelp. Å nøle er å tape (Eraut, 1985, s. 128). Læreren må hvile på rutiner, og stole på egne intuitive avgjørelser basert på praktisk klokskap. Dette kan forstås som utøvelse av skjønn; en form for integrert praktisk kunnskap. Å analysere og 
tolke pedagogiske situasjoner i ettertid kan bidra til å forstå og forbedre praksis, men det vil også kreve intellektuell anstrengelse.

Studentenes oppfatninger av seg selv når de er i praksis, kan ha betydning for hvordan de bruker og kobler sammen ulike kunnskapsformer. Ifølge Ottesen (2007) beror studentenes engasjement på om de går inn i aktiviteten som lærende eller som lærere. I høgskolens undervisning er drivkraften læring, men i praksisperioder skal de også være lærere som driver effektiv undervisning. Lærerstudentenes fokus kan variere i tråd med dette. Den lærende studenten søker teoretisk kunnskap, mens studenten som lærer er mer pragmatisk orientert mot undervisningen. Det forventes imidlertid at profesjonelle lærere kan argumentere for - og begrunne - sine handlinger ut fra generalisert, systematisk kunnskap. Ifølge Kvernbekk finnes det ulike typer teori, og alle teorier skal ikke brukes direkte for å forbedre praksis (2011). Dette betyr likevel ikke at slik teori ikke har betydning for profesjonsutøvelsen. Denne typen teori, som Kvernbekk omtaler som "sterk" teori, har nettopp ved sin distanse til praksis mulighet til å fungere som et kritisk redskap. Slik kunnskap kan imidlertid ikke bringes med inn i klasserommet som en brukerhåndbok. Teorien brukes til å se med, indirekte, for å forstå mer om hva som foregår i praksis, og for å kunne se noe annet enn det man antar at man vet.

Praksissamtalen består av et saksforhold, men også av dialogiske og relasjonelle aspekter (Skagen, 2004). Følelser, tanker, meninger og handlinger vil være integrert i samtalen. Fruktbare veiledningssituasjoner skapes gjennom trygge rammer, omsorg og respekt, slik dialogiske samtaler inkluderer både det relasjonelle og det faglige (Handal \& Lauvås, 2002). I profesjonsutvikling må studentene ha tiltro til at de kan håndtere kravene som stilles, samt at de opplever innholdet som meningsfylt og relevant (Hatlevik, 2014). Studentene kan oppleve et krysspress når de skal gå inn i samtalen både som lærende og som lærere (Ottesen, 2007), fordi de er i både en vurderings- og en veiledningssituasjon. Oppleves dette krysspresset i praksissamtalen, kan det bidra til å skape en sårbarhet hos studentene som kan gi utfordringer videre i samtalen (JohnsenHøines, 2011). Et evaluerende siktemål kan da være til hinder for faglig dialog. Følelser kan påvirke samtaler negativt eller positivt, og utrygghet kan hemme motivasjonen (Boge, Ødegaard, Markhus \& Moe, 2005). En god dialog gir mening og gode følelser hos deltakerne, men har også et faglig innhold som er relevant og utfordrende (Skagen, 2001).

\section{Metode}

\section{Forskningsdesign og utvalgskriterier}

Studien er gjennomført som en kasusstudie. Et forprosjekt med observasjon av en praksissamtale la grunnlag for utvikling av tema i undersøkelsen. I kasusstudien inngår to skoler med én analyseenhet på hver skole. Kriterier for utvelgelse 
av skoler var at undersøkelsen måtte foregå med studenter fra en annen enn vår egen institusjon, det burde ikke være førsteårsstudenter uten erfaring med praksissamtaler fra tidligere, og vi var avhengige av å møte de tre partene i praksisperioden for å kunne observere praksissamtalene og gjennomføre intervjuene rett etterpå. Utvalget ble ellers bestemt ut fra tilgjengelighet. En kontaktperson ved en aktuell høgskole formidlet kontakt med faglærer fra høgskolen som skulle ha praksisoppfølging, og som igjen videreformidlet spørsmålet til praksislærere og respektive praksisgrupper.

Studien er meldt til Personvernombudet for forskning. Alle informantene ble gitt skriftlig informasjon om studien før intervjuene. De bekreftet muntlig før intervjuene at de ønsket å delta, og ga sin tilslutning til at intervjuene kunne bli tatt opp med lydopptaker. På hver skole var det en studentgruppe som deltok i en praksissamtale. Studentgruppen på hver av skolene, og deres forståelse av praksissamtalen slik dette kommer til uttrykk i deres språkhandlinger i intervjuet, utgjorde en analyseenhet. Undersøkelsen foregikk på to ulike skoler.

\section{Datakilder og datainnsamling}

Primærkilden for denne artikkelen er fokusgruppeintervjuer med to studentgrupper som har deltatt i hver sin praksissamtale. Hver studentgruppe som ble intervjuet, bestod av fire andreårsstudenter. I praksissamtalen, som var tema under intervjuet, deltok også praksislærer og faglærer fra høgskolen. Intervjuene ble foretatt på praksisskolene, og ble gjennomført i løpet av en dag på hver av de to skolene i 2013. Praksissamtalene i forkant av intervjuene ble observert og tatt opp på bånd, men fungerer i denne artikkelen bare som bakteppe for oss forskere. Det var utarbeidet en semistrukturert intervjuguide med følgende tema: praksissamtalens hensikt og føringer, forventninger og ønsker, positive eller negative sider/erfaringer ved samtalen, og forståelse for kobling av teori og praksis i samtalen.

\section{Analyseprosessen}

Fokusgruppeintervjuene ble tatt opp på bånd og transkribert. Deretter ble de analysert gjennom meningskoding og kategorisering (Kvale \& Brinkmann, 2012, s. 209). Nøkkelord ble knyttet til tekstavsnitt for å identifisere og kategorisere uttalelser i materialet. Ved hjelp av en matrise undersøkte vi likheter og ulikheter i de to gruppenes ytringer. Når analysen blir gjentatt slik, bidrar dette til å sikre resultatenes gyldighet (Thagaard, 2009). Prosessen har vært abduktiv, med et dialektisk forhold mellom teori og data (s. 199). Gjennom alle faser har prosessen da vært et vekselspill mellom teoretisk forforståelse og ny kunnskap generert fra datamaterialet. Slik fikk empirien reell innflytelse på valg av teoretiske perspektiver underveis.

Hensikten i kvalitativ forskning er å finne meningsinnholdet i informantenes ytringer. Som lærerutdannere er vi del av den samme kulturen som vi undersøker, og vår subjektive tolkning av datamaterialet er verdiladet (Postholm, 
2005, s. 27). Derfor kan funnene heller ikke betraktes som objektive (Thagaard, 2009, s. 43). Men kjennskap til kulturen kan ses på som en fordel for forståelse mer enn et hinder, under forutsetning av at vi presiserer hvilke briller vi ser med, og slik gjør vår egen subjektivitet synlig (s. 207). Som forskere og lærerutdannere har vi en annen posisjon enn studentene. Kunnskapen fra studentintervjuene, basert på fortolkning, vil være foranderlig, da den er relatert til konteksten og relasjonene i hver av studentgruppene (Halkier, 2010, s. 122). Derfor kan ikke kunnskapen generaliseres, men den kan ha overføringsverdi til lignende settinger (Thagaard, 2009, s. 210). Vår undersøkelse var avgrenset, men når metoden er gjort transparent, mener vi at funnene kan fremstå som troverdige.

\section{Resultater}

Funnene presenteres ved hjelp av tre kategorier: 1) Praksissamtalens hensikt, 2) Den faglige praksissamtalen og 3) Studentenes opplevelse av samtalekonteksten. For å anonymisere dataene er skolene nevnt som skole 1 og skole 2, og informantene er identifisert som student 1, 2, 3 og 4 (og omtales som hunkjønn) ved skole 1 og 2 .

\section{Forventninger til praksissamtalens hensikt}

Denne kategorien dreier seg om studentenes forventninger om hva som er samtalens hensikt, og deres egne forventninger til - og ønsker om - hva den skal handle om.

Studentene ved begge skolene fremhevet at hovedhensikten med praksissamtalen var å reflektere over undervisningstimene med utgangspunkt i deres egne erfaringer. Studentgruppen på skole 1 gav uttrykk for at et repertoar av handlinger ville bygges opp, etter hvert som ting ble gjort annerledes og bedre: "Så reflekterer man mer og mer, jo mer erfaring man har. "Studenter ved skole 2 trakk også inn refleksjon “... over hva vi har gjort og at vi kan gi tips til hverandre og si at vi kunne gjort det annerledes og det var kjempebra og det var ikke fullt så bra”. Videre ble refleksjon koblet til egne erfaringer ved en konkret gjennomgang av timen: “... det er veldig fint at vi starter med å gå gjennom hvordan timen var. At vi starter på starten ...” Det ser ut til at refleksjon koblet til egne, konkrete erfaringer og til vurdering av lærerutøvelsen var forstått som hovedhensikten med samtalen.

På skole 1 ble det uttrykt forventning om tilbakemelding på sin undervisning, og få vite “... hva de synes om det vi gjør ...”, få hjelp til å tenke ekstra godt over hva som var bra og som kunne vært gjort annerledes. Dette kan dreie seg om forventninger knyttet til vurdering, behov for støtte, hjelp til å handle og svare riktig, og et ønske om å få svar på hva som virker i praksis. I begge gruppene ble det uttrykt forventninger om råd og tips som kunne bygge opp et forråd av gode lærerhandlinger. På skole 2 ble forventninger også koblet til negative 
erfaringer fra fjoråret om en dårlig forberedt samtale uten faglig innhold. Det ble i den forbindelse uttrykt ønske om mer faglighet i samtalen.

Ellers kom en viss usikkerhet til uttrykk; hvordan samtalen kom til å bli, ville være personavhengig, ble det sagt. Med en uklar og ulik forståelse av samtalens intensjon kan forventningene til samtalene bli ulike. Begge studentgruppene trakk teori inn som element om samtalens hensikt. På skole 2 ble det pekt på at hensikten var “... å få inn mer det teoretiske da, i planleggingen”. Studenten refererte her til informasjon hun hadde fått om dette. Svaret forteller ikke noe om hennes eget syn. En student på skole 1 fortalte at hun nå hadde fått avklart at teori ikke skulle være hovedfokus, og at praksissamtalen ikke skulle dreie seg om å svare på masse teorispørsmål. Teori som praksis i samtalen ble altså noe ulikt forstått og mottatt i de to studentgruppene.

Når det gjelder studentenes forventninger til praksissamtalen, så gav studentene uttrykk for at de ønsket innspill om den gjennomførte undervisningsøkten og at det kunne oppstå gode diskusjoner. "Prøve å få tak i, få noen diskusjoner. Det er egentlig ideelt!” sa en student på skole 1. Det at alle kunne bidra ut fra sitt ståsted med ulik kunnskap og ulik erfaring, ble vektlagt i begge gruppene. "Det blir mange forskjellige synspunkter og måter å se det på," ble det sagt på skole 2. En annen utdypet dette: "Ja, å få frem mest mulig informasjon om det som har skjedd og snakke om det. Alle bidrar med den kunnskapen de har og erfaringer." Det kommer her frem at kunnskapen studentene nevner, er av praktisk art, som dreier seg om å løse praktiske utfordringer. På skole 1 ble det å få andres syn på saken, respekt for andre og mulig uenighet trukket frem som verdifullt. Når studentene på skole 2 betegnet seg selv som et bindeledd mellom praksislærer og høgskolelærer, kom opplevelsen av å høre sammen i et fellesskap til uttrykk. Disse utsagnene kan forstås som uttrykk for positive forventninger til at den faglige praksissamtalen kan være meningsfull for studentene.

\section{Den faglige praksissamtalen}

Denne kategorien omfatter hvordan studentene ser på faglige sider ved samtalen: sammenhengen mellom teori og praksis, spørsmål om læring, og kunnskap som kan komme til uttrykk i praksissamtalen.

Studentene hadde ulike innspill om hvilken plass teorien skal ha i praksisperioden. Studenter ved skole 2 var informert om at teori og praksis skulle kobles, slik dette utsagnet illustrerer: “... for de snakker om det hele tiden. Den teorien og praksisen skal kobles sammen.” $\AA$ være informert om dette vil ikke nødvendigvis bety det samme som å ha en selvstendig forståelse. En annen student i gruppen gav uttrykk for at høgskolens sterke fokus bidro til å øke deres bevissthet, men flere utsagn i begge gruppene tyder på at det å relatere teori til praksis, skjer ubevisst. For eksempel sa en student på skole 1: "Det [teori] ligger jo litt i bakhodet, men det er jo ikke sånn at vi sitter og snakker om Piaget og Vygotsky når vi legger opp undervisning!” Dette kan være uttrykk for at teori oppleves som noe fjernt i studentenes praksisperiode. En av studentene på skole 
2 ga uttrykk for at koblingen nå, når de hadde hatt mer teori på skolen, kom mer naturlig og automatisk: “... jeg føler liksom det ligger i bunnen hele tiden da, om det er bevisst eller ikke.” Teorien var der, litt ubevisst, i bakhodet, men ble ikke verbalisert og relatert til hendelser i klasserommet.

Noen utsagn i gruppe 1 vitner om en skepsis til teori som samtaletema i trepartsamtalen, koblet til undervisningspraksis. "Jeg synes ikke det skal være mer teori i praksis. Jeg synes det heller burde være mer praksis i skolen,” sa en av studentene. Studenten pekte på at erfaringene fra praksis kunne gjøre det lettere å forstå teori på forelesninger. Det motsatte ble ikke påpekt; at praksis kunne forstås ved hjelp av teori. De andre studentene på denne gruppen sa seg enige i at fokus på teori ble "feil". Det kan virke som om praksis og teori av disse studentene ble opplevd som to atskilte områder. Også på skole 2 kom dette til uttrykk ved dette utsagnet: "Praksis er praksis, og skole er skole, tenker jeg. Altså, skolen tar det faglige og praksislæreren tar det i praksis.” En annen av studentene hadde imidlertid innvendinger: "Jeg synes det kunne vært enda mer koblet sammen, jeg.” Hun fikk følge av en medstudent: "Jeg føler jeg mangler litt den teorien.” Her uttrykkes et behov for hjelp til å koble teori og praksis. Vi fant altså noe motstridende oppfatninger om dette, særlig innad i gruppe 2.

Til tross for noen motstridende ytringer, kommer det samlet i materialet frem en viss motstand mot for mye teori og faglighet i praksismøtet. Erfaring og praksis ble vektlagt. En av studentene på skole 1 uttrykte det slik:

Og så tenker jeg det ... Den praksisen som vi har her, er så viktig, for den får vi jo ikke på høgskolen. Der er det kun teorien. Og her kan vi liksom erfare litt i forbindelse med teori uten at vi trenger å sitte og ha en veldig faglig diskusjon, om teori da.

En annen av studentene utdypet poenget om at teoriens plass bør være begrenset:

Ja, for blir det for mye teori, så kan man fort ..., så kan man fort glemme det ... det man egentlig skal snakke om, og det er jo undervisningen.

Her bekreftes en forståelse av at kunnskap fra praksissituasjonen skal være hovedfokus i praksissamtalen om den gjennomførte undervisningen. Dette funnet er, som tidligere påpekt, ikke entydig, men det ble ikke ført sterke argumenter i gruppene for at kobling til teori kan støtte deres profesjonsutvikling. Studentgruppene ble oppfordret til å si noe om kunnskaper, kompetanser og ferdigheter som kunne komme frem i møtet, og som kunne bidra til å utvikle lærerprofesjonalitet. Det kom frem i begge gruppene at møtet kan fremme refleksjon; i gruppe 1 koblet til egen handling, det å få andres syn og få justert eget syn, og i den andre gruppen ved å lære å ta imot tilbakemeldinger på godt og vondt. Det kan se ut som om lærerprofesjonalitet hos begge gruppene ble koblet til refleksjonsbegrepet, der refleksjon dreier seg om å se hendelser i lys av seg selv og innspill i samtalen. 
Når vi oppsummerer funnene om studentenes forståelse av sammenheng mellom ulike kunnskapsformer, er hovedinntrykket at samtalens fokus først og fremst skulle være undervisningen. Teoretiske innspill burde ikke ta fokus fra den praktiske gjennomføringen. Ut fra dette kan det se ut som om praksismøtet ble oppfattet som fristilt fra teori, illustrert ved utsagnet: “... vi har jo ikke mye teori her i praksis.” Det ble ikke på studentenes eget initiativ uttrykt selvstendig forståelse av at kobling mellom teori og praksis kan være hensiktsmessig. Teoretisk kunnskap var til stede, men som noe ubevisst og fjernt. Sammenheng og kobling mellom opplæringens to læringskontekster var ikke tydelig for studentene i dette materialet. Praksiserfaringene var viktige.

Som et gjennomgangstema kom relasjonelle og emosjonelle aspekter ved samtalen stadig til uttrykk i datamaterialet, jf. sekvensen under om det å bli sett. Det viste seg at samtalekonteksten hadde stor betydning for studentene.

S1: Det aller viktigste er kanskje den bekreftelsen som vi får, av både lærer fra skolen og praksislærer, som da sier sin mening om det vi gjorde da. For det er jo veldig viktig å få. [De andre bekrefter med hm.]

S2: Så føler man seg jo litt sett da. Til at de bryr seg, ikke bare plasserer oss i praksis fordi vi skal i praksis og så kommer tilbake på skolen, altså at vi jobber med det å være i praksis. Har et samarbeid.

I studentenes ytringer ble det ikke skilt mellom læring, erfaringer, opplevelser og følelser. I denne konteksten gikk dette over i hverandre for studentene, og opplevelsen av det “å bli sett” av veilederne ble vektlagt.

\section{Studentenes relasjonelle opplevelse av samtalekonteksten}

I denne kategorien kommer studentenes normative forståelse særlig til uttrykk: hvordan samtalen bør eller ikke bør være, og hva som er gode og mindre gode samtaler. Her presenteres studentenes opplevelse av samtalekonteksten, særlig relasjonelle og emosjonelle aspekter, og relatert til tidligere erfaringer.

Studentene på skole 2 pekte på betydningen av god stemning i praksissamtalen. Det ble sagt at når alle deltakerne hadde "et godt bånd mellom seg» kunne studentene bedre tåle å høre forslag til forbedring. Den følgende sekvensen viser hvordan studentene på skole 1 vektla betydningen av et godt sosialt klima:

S2: Altså sånn som i dag så synes jeg det var hyggelig.

S3: Ja

S1: Sånn som vi sa, det har jo veldig mye å si på kjemien.

S2: Ja, det har det.

S1: Og når jeg føler at vi har en grei tone, da er det liksom ikke så ille da.

S3: Ja, og det at man kan sitte og le litt. Og ha det litt ålreit.

S1: Man føler seg jo mye tryggere og mer komfortabel når det er ... når du er med noen som du har kjemi med, at det fungerer greit da. Jeg er sikker på at det hadde vært verre å komme til en sånn trepartsamtale hvis du ikke hadde noe særlig kjemi med de du var i praksis med, da hadde du følt deg mer alene, tror jeg, mer utrygg.

S2: Og det med praksislærer og det med lærer fra høgskolen også.

S1: Ja 
Det ser ut til at en god praksissamtale for studentene kjennetegnes ved harmoni. Gjennom gode relasjoner blir behovet for trygghet ivaretatt. Studentene ga på ulikt vis uttrykk for at krevende spørsmål kunne bryte med den hyggelige stemningen, og samtalen kunne da bli opplevd som "skummel”. Det ble blant annet trukket frem at studentene før praksissamtalen kunne være redde for å bli satt fast. Forståelse av at det kan finnes ett riktig svar, kan skape engstelse for å avsløre manglende kunnskap. Studentene kan også ha et ubevisst forhold til at spørsmål kan være et pedagogisk virkemiddel i samtalen, og at spørsmål for dem dermed ble opplevd som noe negativt.

I begge gruppene vendte studentene stadig tilbake til negative erfaringer fra tidligere praksismøter. De beskrev faglærere fra høgskolen som ikke kom, som ikke brydde seg, og som bare gjorde det de var forpliktet til, eller praksislærer som ikke hadde forberedt møtet: "Den [samtalen] som vi har hatt nå, synes jeg var veldig fin, men i fjor når vi da satt fire eller sju studenter og følte at dette hadde ingen nytte og det var helt katastrofe ..." Det kom ikke helt frem hva det katastrofale var, men den dramatiske uttrykksformen forteller om studentens følelser. En annen av studentene viste også til fjorårets trepartsamtale: "Da følte jeg meg veldig uviktig," sa hun. Slike følelser som erfaringer har etterlatt seg, kan påvirke oppfattelsen av praksismøtet. Studentene gav samlet uttrykk for at det var vanskelig å føle seg trygg i praksismøtet dersom de ikke hadde en relasjon til, eller kjente, faglæreren fra høgskolen. Det kunne da bli kunstig og anspent. "Det er sånn at man gruer seg til det og det burde jo ikke være sånn at man skal grue seg til en trepartsamtale," sa en av studentene. "Vi burde jo ha det [praksissamtale] for at vi studenter skal få noe ut av det da." Behovet for trygghet var grunnleggende for å få utbytte av samtaler.

Studentene i begge gruppene ga uttrykk for at relasjonene mellom studentgruppen og praksislærer var preget av nærhet og respekt. Studentene i gruppe 1 beskrev positive aspekter ved de daglige "topartsamtalene"; de var enklere og mer personlige, sammenlignet med trepartsamtalene. Studentene uttrykte stor respekt for - og tillit til - sine praksislæreres kompetanse. En av studentene på skole 2 sa: "Hun vil forbedre oss, gjøre oss til gode lærere. Hun sier det ikke for å være slem!” Nærheten til elevene i klasserommet ble vektlagt. Kunnskapen hos praksislærer ble anerkjent og verdsatt, slik dette utsagnet på skole 2 illustrerer: "Hun har mye bakgrunnskunnskap om alt." Hun kunne komme med nyttige råd, tips og triks, altså konkrete råd for lærerutøvelse.

\section{Diskusjon}

Artikkelen søker å belyse problemstillingen: Hvordan opplever og forstår læererstudentene praksissamtalens hensikt, innhold og kontekst? Resultatene viser at studentene hadde forventninger om at samtalen skulle dreie seg konkret om undervisningens gang, om hva som hadde gått bra eller mindre bra i timen. 
Studentene ønsket å bygge opp et forråd av gode lærerhandlinger, og de så ikke poenget med å trekke teorien inn i praksissamtalen. Resultatene viser at studentene har en uklar forståelse av teori og teoriens funksjon i samtalen. Bruk av teori ble opplevd som et hinder for deres deltakelse i samtalen. Det er uvisst om denne utryggheten skyldes mangel på teoretisk kunnskap hos studentene. Lærerstudentene tegnet et bilde av hvordan den gode, harmoniske praksissamtalen burde være. Relasjonelle og emosjonelle forhold, som opplevelse av støtte og det å bli sett, ble vektlagt. De ulike funnene i undersøkelsen som refererer til det faglige, det relasjonelle og konteksten som helhet, henger sammen og må ses i lys av studentenes forventinger til praksisopplæringen. Miljøet i konteksten ble av studentene opplevd som en motsats til utfordringer av faglig og teoretisk art.

Praksissamtalen etablerer en felles møteplass. Ved at refleksjon og teori knyttes til studentenes praksiserfaringer, fremmes utvikling av lærerprofesjonalitet (UHR, 2011). Ulike kunnskapsformer får gjennom dette utfylle hverandre og skape helhet i profesjonsutdanningen (Grimen, 2008). Imidlertid ser det ikke ut til at studentene i vår undersøkelse ser en slik helhet. For studentene var praksis i seg selv vektlagt, og hensikten med samtalen var refleksjon over egne praktiske erfaringer. Studentene ønsker først og fremst metodekunnskap; dette er i tråd med funn i andre undersøkelser (Hovdenak \& Fosse, 2014). Ifølge Eraut (1985) kan ønsker om gode råd og tips skyldes et behov for å beherske handlingstvangen i klasserommet bedre. I en dansk undersøkelse (Rasmussen, Laursen, Kruse, Bruun \& Thingholm, 2009), finner vi en lignende forståelse. "Praksisviden" var dominerende blant kunnskapsformene. Dette er teori som praktikeren utvikler for seg selv for å kunne gjennomføre en mer hensiktsmessig praksis og med fokus på hva som virker i klasserommet.

I utsagnet om at praksis er praksis og skole er skole, ligger en implisitt forestilling om at teori og praksis er to atskilte verdener. Dette er i tråd med tidligere forskning; det hersker en forståelse om at det er stor avstand mellom utdanningens teori- og praksisdel (Skagen, 2009; Ludvigsen, 2015). Ifølge Rasmussen et al. (2009) oppfattet studenter høgskolefag, pedagogikk og praksis som et puslespill, og det var vanskelig å se hvordan brikkene hørte sammen. Teori blir trengt mer i bakgrunnen i praksis. Dette bildet er ikke entydig i vårt materiale. I den ene studentgruppen ble det gitt uttrykk for at praksissamtalen manglet noe vesentlig når teori var fraværende. Følger vi Rasmussen et al. (2009), kan dette tyde på at det i denne studentgruppen var en større synteseforståelse av forholdet mellom skolefagene, pedagogikk og praksis. Hovedfunnet er imidlertid at begrepsparet teori og praksis i vårt materiale blir forstått som en dikotomi, ikke som en integrert helhet. Resultatet av dette synet kan være at samtalen tuftes på et haltende kunnskapsgrunnlag (Kvernbekk, 2011; Hovdenak \& Fosse, 2014).

Det er en fare for at praksissamtalen gjentakende kretser om det konkrete, ut fra studentenes behov for praktiske grep og teknikk som presses frem under handlingstvangen i klasserommet. Men ifølge Kvernbekk (2001) vil førstehåndserfaringene alene ikke være tilstrekkelige for å kunne utvikle lærerprofe- 
sjonalitet. Erfaringskunnskap er partikulær og derved begrenset, da den er knyttet til konkrete situasjoner, personer og handlinger. Dersom erfaringer utelukkende reflekteres over - og drøftes - relatert til andre erfaringer og opplevelser, vil det være vanskelig å utvikle denne "praksisviden" til en mer generell forståelse av allmennpedagogiske utfordringer i klasserommet. For mer utdypende pedagogisk innsikt vil studentene ha behov for mer generalisert, vitenskapelig fundert kunnskap som er til å stole på (UHR, 2011; Kvernbekk, 2011). Slik grunnleggende og generell innsikt er et viktig siktemål i opplæringen for de lærende lærerstudentene (Ottesen, 2007). I vårt materiale kan det se ut som om studentene først og fremst oppfatter seg som lærere når de er i praksis, og ikke som lærende i forhold til den helhetlige utdanningen. Det å være lærende knyttes da mer til undervisningen på campus. Det er viktig at studentene opplever at det de driver med er meningsfullt (Hatlevik, 2014), men det ser ut til å være en utfordring for studentene i vårt materiale å finne mening i å koble de ulike kunnskapsformene når de er i praksis. Transformasjon av kunnskap mellom de ulike kontekstene kan være et læringsproblem for studentene, slik Fosse (2016) påpeker. Ifølge Ludvigsen (2015) er det viktig å få artikulert og formalisert de ulike kunnskapsformene for å kunne utvikle kunnskapsgrunnlaget. Det er vesentlig å kunne integrere ulike kunnskapsformer slik at profesjonsforståelse kan utvikles (Rørnes, 2015). Det er samspillet mellom ulike former for kunnskap som kan lede mot kloke handlinger i profesjonelt lærerarbeid. Å snakke om førstehåndserfaringer alene vil da være utilstrekkelig.

Resultatene viser at studentene hadde et fortrolig forhold og tillit til praksislærer som fagperson og ekspert i klasserommet. Vi fant at studentene sammenlignet trepartsamtalen med den daglige "topartsamtalen" de hadde med sin praksislærer. To ulike samtalesituasjoner, i utgangspunktet vesensforskjellige og ikke sammenlignbare, ble sammenlignet. Faglærer fra høgskolen ble betegnet som en utenforstående. Dette kan tolkes som en insider/outsider-forståelse av praksislærer kontra høgskolelærer (Kvernbekk, 2001). Det kan være "førstehåndserfaringens autoritet” som her gjør seg gjeldende. Praksissamtalen mellom de tre partene vil i sin natur ikke kunne bli så nær, uformell og trygg som de daglige veiledningsmøtene med praksislærer. Når studentene likevel sammenlignet disse to, kan det forklares ut fra funnene om deres noe uavklarte forståelse av praksissamtalens hensikt. Studentene tegnet også en harmonimodell av "den gode praksissamtalen”. I likhet med de daglige "topartsamtalene”, burde trepartsamtalen være hyggelig og uformell. Kanskje kan noen utfordringer når det gjelder å skape trygghet i konteksten "løses" ved en bedre, mer dialogisk samtaleform, og ved å tydeliggjøre betydningen av gjensidig respekt i samtalen. Likevel vil det være en kontinuerlig utfordring å finne en god balanse mellom det å skape et positivt samtaleklima og å stille krav i praksissamtalen.

Praksissamtalen var ikke bare en faglig samtale for studentene i vår undersøkelse, men et møte mellom mennesker, et relasjonelt forhold. Når samtalens forløp er personavhengig, slik funnene indikerer, vil hver samtalekontekst være 
ulik, og det vil variere i hvilken grad teori bevisst trekkes inn eller tones ned. De ulike "stemmene" i samtalen vil påvirke samspillet, positivt eller negativt, både relasjonelt og faglig (Skagen, 2001). Dersom studentene selv våger - og viser vilje til - å gå inn i praksissamtalen som en faglig samtale, må samtalekonteksten oppleves som dialogisk og støttende. Det er grunn til å ta på alvor at studentene i vårt materiale dro med seg uavsluttede erfaringer fra tidligere som kunne hemme deres positive deltakelse i fremtidige praksissamtaler. Det er forståelig at studenter har behov for å snakke om hendelser fra timen for å bearbeide erfaringene sine. I dialogen skal alle parter oppleve å bli sett og møtt med respekt og likeverdighet. Dette er grunnleggende for at samtalen skal oppleves som meningsfull, relevant og utfordrende for alle parter (Dysthe, 2001; Skagen, 2009; Hatlevik, 2014). Det å føle seg uviktig, slik den ene studenten sa, eller å føle at lærerne ikke bryr seg, gir en opplevelse av å ikke være verdsatt. Slike erfaringer kan gi dårlige utgangspunkt for kommende praksissamtaler, med sannsynlighet for svak studentdeltakelse som konsekvens.

Våre resultater indikerer at studentene ikke betraktet teoretiske innspill som naturlige element i praksissamtalen. Når lærerutdanningen er tuftet på et vekselspill mellom ulike kunnskapsformer, må både teoriundervisning på høgskolen og praksisopplæring i grunnskolen tydeliggjøre denne interaksjonen. Praksissamtalen som en faglig samtale kan ikke reduseres (Handal \& Lauvås, 2002), og teori kan ikke utelukkes som briller til å se med (Kvernbekk, 2001). Det er vanskelig for studenter å finne veien helt alene; derfor må konteksten være støttende og preget av respekt og tillit (Tveiten, 1998; Handal \& Lauvås, 2002). Men studentene må selv finne mening i det å skape syntese i utdanningens teori- og praksisdel (Dysthe, 2001; Rasmussen, 2007).

Undersøkelsen viser at praksis for studentene hadde stor verdi i seg selv, og undervisningsforløpet ble forstått som det egentlige innholdet i praksissamtalen. Studentene kunne oppleve spørsmål som utfordrende og krevende. Når de ble stilt teoretiske spørsmål, kunne de oppleve sårbarhet og utrygghet. Dette kommer også frem i andre undersøkelser (Boge, Ødegaard, Markhus \& Moe, 2005; Johnsen-Høines, 2011). Det kan føre til at praksissamtalens gylne mulighet til å hjelpe og støtte studentene i å koble ulike kunnskapsformer, blir oversett eller forbigått. Å tone ned teoretiske aspekter kan oppleves som mer komfortabelt for studentene. Men det kan også skape en falsk trygghetsfølelse. I en iver etter å møte studentene og gi positiv støtte, kan det ligge en fare for at det faglige innholdet tones ned med den følge at faglig utvikling hemmes. For å fremme faglig utvikling kan det å utfordre like gjerne betraktes som en støtte, også om det vil innebære intellektuelle anstrengelser (Eraut, 1985). Forståelsen av at det i hver praksissamtale ligger en kime til utvikling av lærerprofesjonalitet, kan betraktes som hjelp og støtte til stadig å tøye og utvide de lærende sine nærmeste utviklingssoner (Vygotsky, 1978; Säljö, 2002). Spørsmål og hint som oppmuntrer til refleksjon og selvstendig tenkning kan støtte studentenes læring. Det 
som blir viktig, er å skape et rom der både kritiske innspill og utfordringer kan drøftes ut fra ulike kunnskapsformer.

Denne studien har noen styrker og svakheter det må tas hensyn til når dataene tolkes. En styrke ved studien er at den omhandler et tema som i liten grad er omtalt i tidligere forskning, og som er av betydning for utvikling av grunnskolelærerutdanningene. En svakhet ved studien er at få studenter inngår i utvalget og at studentene kommer fra samme høgskole.

\section{Oppsummering og pedagogiske implikasjoner}

Studentene i denne studien ser ikke betydningen av teoriens plass i praksisopplæringen. Dette kan skyldes at de oppfatter seg selv som lærere når de er i praksis, og ikke som lærende studenter. Dersom det er slik at de har et mangelfullt teoretisk kunnskapsgrunnlag, vil denne kunnskapen ligge utenfor deres virkelighetsforståelse. Da vil de heller ikke være bevisste på hva de ikke vet. Det vil heller ikke foregå noen transformasjon mellom ulike kunnskapsformer og mellom campus og skole.

Denne artikkelen problematiserer faglige og menneskelige utfordringer for likeverdig og dialogisk deltakelse i praksissamtalen. Å skape vekselspill mellom ulike kunnskapsformer i en forskningsbasert og praksisnær lærerutdanning kan betraktes som en form for balansekunst i praksissamtalen. Utfordringer og støtte kan av studentene oppfattes som motsetninger, men for læring og utvikling av lærerprofesjonalitet må begge deler være til stede. Det vil derfor fremover være stort behov for forskning om praksissamtalen som en del av den helhetlige opplæringen i GLU, som et bindeledd mellom ulike kunnskapsformer og mellom utfordring og støtte.

Studentene i datamaterialet uttrykker uklare og ulike forventninger til praksissamtalen. For at samtalen skal være dialogisk og bidra til utvikling av lærerprofesjonalitet, er det derfor nødvendig å avklare føringene og forventningene for samtalens faglige innhold både på overordnet nivå og i hver enkelt samtale. Forståelse av både det relasjonelle og det faglige, samt avklaring av forventninger, må ligge til grunn for organisering av den fremtidige praksisopplæringen. En faglig dialog må etableres i hver praksissamtale, slik at den kan springe ut fra et allsidig kunnskapsgrunnlag.

\section{Referanser}

Boge, M., Ødegaard, E., Markhus, G. \& Moe, R. (2005). Læring gjennom veiledning: meningsskaping i grupper. Bergen: Fagbokforlaget.

Dysthe, O. (2001). Sosiokulturelle teoriperspektiv på kunnskap og læring. I O. Dysthe (red.), Dialog, samspel og leering (s. 33-72). Oslo: Abstrakt forlag. 
Eraut, M. (1985). Knowledge creation and knowledge use in professional contexts. Studies in Higher Education, 10(2), 117-133. Hentet 14.05.2016 fra http://dx.doi.org/10.1080/03075078512331378549

Fosse, B. O. (2016). Transformering av kunnskap mellom campus og skole i lærerutdanningen. Acta Didactica Norge, 10(2), 235-251. Hentet 25.10.2016 fra https://www.journals.uio.no/index.php/adno/article/view/2498

Grimen, H. (2008). Profesjon og kunnskap. I A. Molander \& L. Terum (red.), Profesjonsstudier (s. 71-86). Oslo: Universitetsforlaget.

Halkier, B. (2010). Fokusgrupper. I S. Brinkmann \& L. Tanggaard (red.), Kvalitative metoder. En grundbog (s. 121-135). København: Hans Reitzels Forlag.

Handal, G. \& Lauvås, P. (2002). Veiledning og praktisk yrkesteori. Oslo: Cappelen Akademisk Forlag.

Hatlevik, I. K. R. (2014). Meningsfulle sammenhenger. En studie av sammenhenger mellom laring på ulike arenaer og utvikling av ulike aspekter ved profesjonell kompetanse hos studenter i sykepleier-, lcerer- og sosialarbeiderutdanningene. Doktoravhandling, Høgskolen i Oslo og Akershus. Hentet 25.10.2016 fra http://hdl.handle.net/10642/2397

Hovdenak, S. S. \& Fosse, B. O. (2014). Lærerutdanning og lærerprofesjonalitet i spenningsfeltet mellom ulike kunnskapsformer. Norsk Pedagogisk Tidsskrift, 98(02), 66-77.

Johnsen-Høines, M. (2011). Praksissamtalens sårbarhet. Tidsskriftet FoU i praksis, 5(1), 4765. Hentet 28.02.2015 fra http://tapir.pdc.no/pdf/FOU/2011/2011-01-4.pdf

Kvale, S. \& Brinkmann, S. (2012). Det kvalitative forskningsintervju (2. utgave). Oslo: Gyldendal Akademisk.

Kvernbekk, T. (2011). Filosofisk om teori og praksis. Bedre skole, 2, 20-25. Hentet 25.10.2016 fra https://www.utdanningsforbundet.no/upload/Tidsskrifter/Bedre\%20Skole/BS_nr_211/UTD-BedreSkole0211-WEB_Kvernbekk.pdf

Kvernbekk, T. (2001). Erfaring, praksis og teori. I T. Kvernbekk (red.), Pedagogikk og lererprofesjonalitet (s. 146-163). Oslo: Gyldendal Akademisk.

Ludvigsen, S. (2015). Fagfornyelse, dybdelæring og progresjon i lærerutdanningen. I U. Rindal, A. Lund \& R. Jakhelln (red.), Veier til fremragende læererutdanning (s. 221-227). Oslo: Universitetsforlaget.

Ottesen, E. (2007). Teachers "in the making”: Building accounts of teaching. Teaching and Teacher Education 23(5), 612-623. Hentet 02.05.2016 fra http://www.sciencedirect.com/science/article/pii/S0742051X07000121

Postholm, M. B. (2005). Kvalitativ metode. En innføring med fokus på fenomenologi, etnografi og kasusstudier. Oslo: Universitetsforlaget.

Rasmussen, J. (2007). Trepartsamtalen. Et forsøgs- og udviklingsarbejde ved Skive Seminarium, CVU Midt-Vest. Hentet 20.05.2015 fra http://www.ekspertiundervisning.dk/index.php/litteratur

Rasmussen, J., Laursen, P. F., Kruse, S., Bruun, T. H. \& Thingholm, H. (2009). Ekspert i undervisning. København: Danmarks Pædagogiske Universitetsskole. Hentet 20.05.2015 fra

http://ekspertiundervisning.dk/images/stories/file/Samlet\%20rapport\%20final\%20251009. pdf

Rørnes, K. (2015). Universitetsskoler i lærerutdanningen; å koble praksis og teori i lærerutdanningen. I U. Rindal, A. Lund \& R. Jakhelln (red.), Veier til fremragende lererutdanning (s. 75-86). Oslo: Universitetsforlaget.

Skagen, K. (2001). Veiledningssamtaler i bakhtinsk perspektiv. I O. Dysthe (red.), Dialog, samspel og læering (s. 197-218). Oslo: Abstrakt forlag.

Skagen, K. (2004). I veiledningens landskap. Kristiansand: Høyskoleforlaget. 
Skagen, K. (2009). Veiledning i praksis. Om praksisopplæring i norsk allmennlærerutdannelse. Acta Didactica Norge, 3(1), Art. 8. Hentet 20.05.2015 fra https://www.journals.uio.no/index.php/adno/article/view/1036

Säljö, R. (2002). Læring, kunnskap og sosiokulturell utvikling: Mennesket og dets redskaper. I I. Bråten (red.), Læring i sosialt, kognitivt og sosialt-kognitivt perpsektiv (s. 31-57). Oslo: Cappelen Akademisk Forlag.

Thagaard, T. (2009). Systematikk og innlevelse. En innføring i kvalitativ metode. Bergen: Fagbokforlaget.

Tveiten, S. (1998). Veiledning - mer enn ord. Bergen: Fagbokforlaget.

UHR (2011). En helhetlig tilnœrming til læererutdanning. Universitets- og høgskolerådet, Nasjonalt råd for lærerutdanning. Hentet 04.03.2015 fra http://www.uhr.no/documents/HelhetligEndelig_versjon_september2011.pdf Vygotsky, L. (1978). Mind in Society. Cambridge: Harvard University Press. 